\title{
JOSHI NI, DE, DAN $O$ SEBAGAI KATEGORI POSTPOSISIONAL/PEMARKAH DALAM BAHASA JEPANG: KAJIAN SINTAKTIS DAN SEMANTIS
}

\author{
Titien Rostini \\ STBA YAPARI, Bandung
}

\begin{abstract}
Abstrak
Hasil penelitian tipologis terhadap bahasa-bahasa di dunia menunjukkan adanya berbagai corak pola urutan yang masing-masing memiliki corak internal bawahannya sendiri yang menyangkut bermacam-macam konstruksi yang ada di dalamnya. Bahasa Jepang (BJ) sebagai salah satu bahasa asing di Indonesia memiliki berbagai jenis karakteristik yang berbeda dengan struktur bahasa Indonesia. Secara tipologis, perbedaan yang paling mencolok adalah BJ memiliki linearitas kata S-O-P yang bersifat postposisional dalam bentuk partikel yang secara obligatoris muncul dalam kalimat. Secara hipotesis, dinyatakan bahwa partikel BJ berjumlah sekitar 70 jenis. Kehadiran partikel dalam kalimat bersifat multifungsi. Selain itu, dalam BJ sering ditemukan adanya partikel rangkap (double particles).Tulisan ini akan mendeskripsikan ihwal partikel ( $n i$, de, dan o) baik yang berfungsi sebagai pemarkah (markers) atau sebagai postposisional. Selain itu, akan dikaji pula dengan melibatkan pemahan makna aspektualitas, aksionalitas dan temporalitas.
\end{abstract}

Kata kunci: postpositional, pemarkah, bahasa Jepang, sintaksis, semantis

\begin{abstract}
Researches on the typology of languages in the world has shown the variety of word order that each of which has its own internal sub-category in relation with the types of its inner construction. The Japanese language as one of foreign languages in Indonesia has different characteristics from that of the structures of Indonesian language. Typologically, the most sallient difference is that Japanese langanage has linearity of word order S-O-P which its forms of particle are postposiyional and is obligatory to occur in sentences. Hypothetically, it is stated that there are approximately 70 types of particle in Japanese language. The occurence of particle in Japanese sentemnce is multifunctional. Beseides, Japanese language has double particles. This study aims to descricbe the particles ni, de, and o, which both function as markers and postpositional. For adding, this study also deals with the meaning of aspectuality, actionality, and temporality.
\end{abstract}

Keywords: postpositional, markers, Japanese language, syntactic, semantic. 


\section{Pendahuluan}

Keselarasan pola urutan BJ adalah Subjek - Objek - Predikat (SOP). Sentralisasi predikat yang dapat diisi oleh verba, nomina, dan/atau adjektiva tersebut memiliki konstruksi postposisional yang sangat ajeg, yaitu modifier yang selalu mendahului inti. Kridalaksana (1993:176) menyatakan bahwa postposisi adalah partikel yang dalam bahasa OV terletak di belakang nomina dan menghubungkannya dengan kata lain dalam ikatan eksosentris yakni menyangkut pemahaman terhadap salah satu unsur pembentuk frasa yang tidak dapat berdistribusi mengisi fungsi sintaksis. Hal tersebut sesuai dengan pernyataan lori Isao (2001:37) bahwa: 日本語の基本的な語順は「「修飾部十主要部」’ Pola urutan kata dalam bahasa Jepang menunjukkan bahwa modifier selalu mendahului inti'.

Konstituen postposisi berfungsi untuk menandai hubungan antara konstituen di depan postposisi dan konstituen di belakangnya. Hal tersebut dapat menjadi penguasa dan dapat pula menjadi pembatas (Binding Government Theory). Hubungan penguasapembatas tersebut digunakan untuk mengkaji hubungan antara nomina/pronomina postposisi dan postposisi - verba. Penguasa (government) dipahami sebagai unsur yang menentukan hubungan antara inti konstruksi dan kategori lainnya yang ada hubungannya dengan konstruksi tersebut, sedangkan pembatas (binding) dipahami sebagai unsur yang dikuasainya.

Di dalam bahasa Indonesia, partikel dan preposisi termasuk kata tugas. Alwi,dkk (1998:287-288), menyatakan bahwa kata tugas hanya mempunyai arti gramatikal dan tidak memiliki arti leksikal. Lebih lanjut dinyatakan bahwa berdasarkan peranannya dalam frasa atau kalimat, kata tugas dibagi menjadi lima kelompok: (1) preposisi, (2) konjungtor, (3) interjeksi, (4) artikula, dan (5) partikel penegas. Secara semantis, preposisi yang juga disebut kata depan, menandai berbagai hubungan antara konstituen di depan preposisi tersebut dengan konstituen di belakangnya. Secara sintaktis, preposisi berada di depan nomina, adjektiva, atau adverbia sehingga terbentuk frasa preposisional. Berdasarkan bentuknya, preposisi ada dua macam, yaitu preposisi tunggal dan preposisi majemuk.

Di dalam bahasa Jepang, istilah preposisi disebut 「前置詞 'zenchishi'」sedangkan postposisi disebut「後置詞 'kouchishi. Yamazaki et.all (1994:292) menyatakan bahwa preposisi dalam bahasa Jepang bersifat postposisional [後置詞] dengan penjelasan sebagai berikut.

名詞または名詞句の後ろにくる語または形容詞で、位置、方、所有などを表 す。たとえば、日本語にこの例がみられる：東京から。

'Postposisi (kochishi) adalah jenis kata yang muncul setelah nomina / frasa nomina atau adjektiva yang dapat mengungkapkan makna lokasional dan sebagainya. Misalnya, 東 京から (Tokyo kara 'dari Tokyo').

Kendati demikian, pada kenyataannya sering terjadi kesalahan dalam pemahaman kaidah tersebut. Contoh yang diberikan Yamazaki yaitu frasa Tokyo kara 'dari Tokyo' , mudah diidentifikasi yaitu, konstituen Tokyo berfungsi sebagai binding (pewatas) dan konstituen kara 'dari' berkategori postposisi yang berfungsi sebagai government (penguasa). Akan tetapi, ketika dalam telaah klausa, misalnya dalam klausa Tokyo kara kimashita 'Datang dari Tokyo', konstituen Tokyo berfungsi sebagai pewatas, konstitien kara 'dari' sebagai penguasa, dan konstituen kimashita 'datang' sebagai pewatas. Dengan demikian, telaah postposisional harus dikaji pula secara kontekstual. 
Secara sintaksis, di dalam kalimat BJ, selalu terdapat partikel (joshi) yang bersifat obligatoris. Kridalaksana (2001:155) menyatakan bahwa partikel (particle,grammatical word, closed class word, empty word, function word, structural word), adalah kata yang biasanya tidak dapat diderivasikan atau diinfleksikan, mengandung makna gramatikal dan tidak mengandung makna leksikal. Dengan demikian, secara kategorial, postposisi termasuk partikel yang dalam bahasa Jepang disebut Joshi . Takamizawa, et.all (2004:99) menyatakan bahwa Joshi adalah いろいろな語に付いて、語と語の関係を表したり文の最後に付 いて意味を添えたりする付属語。格助詞、終助詞、接続助詞、副助詞などに分類 されている…/

Dari penjelasan tersebut dapat dipahami bahwa Joshi adalah jenis kata yang termasuk kategori fuzokugo yakni jenis kata yang tidak dapat berdiri sendiri dan tidak berkonjugasi (nonparadigmatis). Fungsi joshi adalah untuk menyambungkan antarkata atau antarkalimat. Joshi terbagi atas empat bagian, yaitu, 1) kakujoshi (joshi yang diletakan dibelakang nomina). 2) Setsuzokujoshi (joshi dalam bentuk konjungsi yang diletakan dibelakan verba atau ajektiva) 3) Fukujoshi (joshi yang dapat diletakan dibelakang diseluruh jenis kata dan menunjukkan suatau batasan atau derajat), dan 4) Shuujoshi (joshi yang muncul di akhir kalimat). Seluruh joshi tersebut memiliki fungsi dan makna yang berlainan. (Periksa pula: Kenbo, 1992:556; Yamada Yoshio, 1986:3 dan Hashimoto Shinchiki, 1986:3).

Pemerian istilah joshi sering dikacaukan dengan konjungsi (setsujokushi) setsujokujoshi). Hal tersebut sangat dimungkinkan karena seperti yang tampak pada bahasan sebelumnya bahwa salah satu bagian dari joshi adalah setsujokujoshi (konjungsi yang pada umumnya digunakan di belakang verba atau ajektiva) dan berfungsi untuk menghubungkan antarkalimat. Selain itu, postposisi memiliki kemiripan dengan konjungsi yakni memiliki fungsi untuk menghubungkan antarkalimat. Dengan demikian dapat dinyatakan bahwa postposisi menyatakan hubungan predikatif, sedangkan konjungsi menyatakan hubungan koordinataif atau subordinatif.

Postposisi BJ dapat diungkapkan melalui tiga jenis joshi yaitu joshi ni, de, dan o karena ketiga jenis joshi tersebut memiliki perilaku yang berlainan baik dilihat dari segi struktur sintaksis maupun semantisnya. Secara sintaktis, joshi ni, de, dan o adalah morfem terikat sintaksis (syntactically bound morpheme), yaitu morfem yang tidak dapat dilekatkan pada morfem lainnya. Secara semantis, hasil proses pembentukan verba yang dilekati oleh salah satu morfem terikat morfologis tersebut bersifat semantik fungsional yang dapat mewujudkan berbagai jenis mmakna.

Di dalam bahasa Indonesia, sebuah partikel hanya dapat mengungkapkan satu makna sedangkan sebuah partikel dalam BJ dapat mengungkapkan berbagai jenis makna. Hal tersebut tentu saja akan menambah tingkat kesulitan bagi masyarakat Indonesia yang sedang mempelajari BJ. Terlebih dengan adanya pemahaman bahwa baik preposisi dan postposisi dapat dikaji berdasarkan makna aspektualitas, aksionalitas (makna inheren verba), dan temporalitas.

Aspektualitas, aksionalitas, dan temporalitas merupakan konsep semantik yang berhubungan dengan unsur waktu. Sehubungan dengan hal tersebut, Tadjuddin (1993:2628) menyatakan bahwa pada kategori temporalitas unsur waktu bersifat lokatif, mengacu pada waktu-waktu absolut dan/atau waktu relatif dan, pada umumnya, berorientasi pada waktu ujaran (speech moment). Oleh karena itu, temporalitas tergolong kategori deiktik, unsur waktu bersifat eksternal (di luar situasi), dan menunjuk ke lokasi waktu-waktu absolut 
atau waktu relatif. Sementara itu, aspektualitas termasuk kategori nondeiktik, unsur waktu bersifat internal (di dalam situasi) yang dapat diungkapkan melalui afiks, partikel, makna inheren verba, dan dalam tataran sintaksis diungkapkan melalui tataran klausa, kalimat dan/ atau dalam bentuk wacana. Aspektualitas sebagai kategori semantik fungsional, mengacu pada gejala aspektualitas pada umumnya mengenai unsur waktu internal situasi, yang bentuk pengungkapannya tidak terbatas hanya pada bentuk-bentuk morfologi, melainkan meliputi berbagai perangkat bentuk yang mungkin ada dalam suatu bahasa.

Di dalam BJ, kalimat yang mengandung joshi ni, de, dan o bersifat multifungsi dapat menggambarkan berbagai jenis situasi. Dalam hal situasi, Comrie (1976:41-51), membagi verba menjadi tiga jenis situasi beroposisi biner yang ditinjau berdasarkan (a) ada tidak adanya proses dalam suatu situasi (pungtual dan duratif); (b) ada tidaknya titik akhir alamiah (telis dan atelis) dan, (c) ditinjau dari ada tidaknya tahapan dalam berlangsungnya situasi (statis dan dinamis).

Vendler (1967:106-107) menyatakan bahwa berdasarkan skemata waktu (time schemata) yang digunakan oleh sebuah verba terdapat empat jenis situasi yang berlainan, yaitu; a) Activities 'aktivitas' diungkapkan melalui verba aktivitas menggambarkan situasi sedang berlangsung dan terdiri atas beberapa tahapan yang saling mengikutinya b) Accomplishment 'penyelesaian', menggambarkan situasi yang sedang berlangsung dalam kurun waktu tertentu dan memiliki potensi untuk mencapai batas akhir situasi. c) Achievements 'pencapaian' yakni situasi verba yang memiliki persamaan dengan verba aktivitas yaitu tidak menunjuk kepada proses yang sedang berlangsung. d) Verba pencapaian terjadi dalam satu saat dan menempati waktu tertentu, dan e) States 'keadaan' yang menggambarkan adanya situasi yang berlangsung dalam periode tertentu.

Untuk memahami perwujudan situasi telis-atelis bahasa Jepang (istilah Kudou Mayumi (1995:33-34), 限界一非限界 (genkai'telis' - higenkai 'atelis'), dalam upaya pemahaman ke dalam bahasa Indonesia, dapat dipertimbangkan berdasarkan teori-teori Djajasudarma (2000321-325) yang mengungkapkan adanya studi aspektologi dengan melibatkan path of the theme 'lajur tema' (LT) yang berhubungan dengan ruang dan waktu (spatio-temporal) dan berkaitan erat dengan valensi skema gerak (move). Menurut Djajasudarma LT berhubungan dengan ruang ( $R$ ) diikuti sumber (S), dan sasaran (Goal-G) sebagai pewatas verba (sebagai predikat) bagian dari predikasi. Verba "ruang" yang berhubungan dengan bahasa Indonesia dapat menginklusifkan preposisi baik statif maupun dinamis (direktif) (Periksa pula Kudou Mayumi, 1995: 33). Hal tersebut sesuai dengan apa yang telah dinyatakan oleh Seichi Makino \& Michio Tsutsui (1986:349-351) bahwa salah satu fungsi partikel $o$ adalah a particle which indicates a space in/on/across/through/along which s.o. or s.t.moves).

Melalui metode penelitian deskriptif yang bersifat kualitatif berdasarkan kriteria validitas data dan teknik penelitian yang diawali dengan pencatatan dan pengartuan data dalam bentuk tulisan, data yang terkumpul dikaji berdasarkan fenomena yang muncul dan disesuaikan dengan kaidah-kaidah yang berlaku dalam pembentukan postposisi BJ. Teknik kajian yang digunakan adalah distribusional dengan pertimbangan bahwa alat penentu dalam mengkaji data adalah unsur bahasa itu sendiri dalam hal ini adalah bahasa Jepang. seperti pada contoh-contoh berikut. 
Joshi Ni, De, dan O ......

(1) 部屋 に います。

heya ni imasu.

Kamar di ada

'Ada di kamar'

(2) 学校の前にバスをおります。

Gakkou no mae ni basu o orimasu.

Sekolah depan di basu dari turun

'Turun (dari) bus di depan sekolah.'

(3) 部屋で母に手紙を書きます.

Heya de haha ni tegami o kakimasu.

Kamar di ibu kepada surat menulis.

'Menulis surat kepada ibu di kamar'

(4) 部屋を出ます。

heya o demasu'

Kamar keluar

Keluar dari kamar'

Secara sintaksis, kostituen $n i$ ' $\mathrm{di}^{\prime}$ pada contoh (1) berkategori postposisional (penguasa) yang bervalensi dengan veba eksistensial imasu 'ada' pengungkap makna eksistensial (statis). Verba pada jenis ini menunjuk kepada proses yang sedang berlangsung dalam waktu panjang atau pendek yang tidak tentu.

Pada contoh (2), Postposisi ni mengungkapkan makna lokasional yang menunjukkan lokasi terjadinya (ruang/spasi) dalam stuasi (peristiwa) yang dilakukan oleh nomina/ pronomina. Dengan demikian, frasa postposisi dalam gakko no mae ni 'di depan sekolah' berfungsi sebagai pewatas sedangkan postposisi $o$ (penguasa) pengungkap makna transisional/penguasa dalam klausa basu o oriru 'turun (dari) bus' .

Partikel ni pada (3) berfungsi sebagai pemarkah objek tak langsung, konstituen de sebagai postposisi lokasional, dan partikel o berfungsi sebagai pemarkah objek. Hal tersebut dikemukakan, karena objek adalah konstituen kalimat yang kehadirannya dituntut oleh predikat dalam bentuk verba transitif pada kalimat aktif.

Partikel o pada (4) berketegori postposisional yang menyatakan hubungan asal (source) yaitu sumber (S) dalam bentuk nomina + postposisi yang menggambarkan hubungan semantis dengan verba (demasu 'keluar') dan mengungkapkan adanya titik awal dari suatu aktivitas (Origin or starting point of motion).

\section{Hasil dan Pembahasan}

Berdasarkan contoh-contoh dan penjelasan yang telah dikemukakan tampak bahwa joshi ni, de, dan o dalam BJ memiliki multifungsi yaitu termasuk kategori postposisi atau partikel sehingga agak sulit dibedakan dengan pemarkah. Akan tetapi, seperti yang telah dijelaskan sebelumnya bahwa postposisi adalah kategori yang terletak di belakang unsur kategori lain, terutama nomina sehingga terbentuk frasa eksosentris. Selain itu, joshi ni, de, 
dan $o$ dalam BJ bersifat multifungsi yakni dapat berfungsi sebagai pemarkah (marker) atau berkategori postposisional yang dalam kalimat BJ sering muncul secara bersamaan. Untuk lebih jelasnya berikut ini disajikan perihal ke tiga jenis partikel tersebut.

\subsection{Joshi $\mathrm{Ni}$}

Kehadiran joshi ni dalam sebuah klausa atau kalimat berkategori postposisional dengan ni sebagai penguasa yang didahului nomina (pembatas). Kehadiran partikel ni yang berkategori postposisi pada contoh (5) dan (6) bersifat statis sedangkan pada contoh (7) dan (8) bersifat dinamis. Situasi dinamis seperti demikian tercermin dengan adanya proses peralihan, perpindahan, atau gerak yang menyertainya.

(5) ホテルにとまります。

hoteru ni tomarimasu.

hotel di menginap

'Menginap di hotel'

(6) 教室にいます。

Kyoushitu ni imasu

Kelas di ada

'Ada di kelas'

(7) トイレに入ります。

toire ni hairimasu

toilet ke masuk

'Masuk ke toilet'

(8) バスにおります

Basu ni orimasu

Bus dari turun

'turun dari bus'

Secara sintaktis, postposisi ni (penguasa) yang diikuti verba statis tomarimasu 'menginap' pada (5) dan verba imasu 'ada' (6) hanya menggambarkan situasi eksistensial. Keberlangsungan situasi statis tersebut bersifat homogen (keadaan tetap) tanpa disertai perubahan atau gerakan (nondinamis). Secara semantis, postposisi ni pada (7) dan (8), bersifat dinamis. Selain itu, frasa postposisi toire ni 'ke toilet' pada (7) mengambarkan hubungan direksional sedangkan hubungan semantis antara frasa postposisi basu ni 'dari bus' pada (8) menggambarkan adanya titik awal dari suatu aktivitas.

\subsection{Joshi De}

Kehadiran joshi de yang berfungsi sebagai postposisi dalam kalimat BJ memiliki lima jenis makna yaitu instrumen, kausalitas, komitatif, temporalitas dan situasi pengungkap makna aktivitas seperti pada contoh-contoh berikut. 
Joshi Ni, De, dan O......

(9)はしでご飯を食べます。 hashi de gohan o tabemasu sumpit dengan nasi makan 'Makan nasi dengan (menggunakan) sumpit'

(10) 自転車で学校へ行きます。 jitensha de gakkou e ikimasu. Sepeda dengan sekolah ke pergi 'Pergi ke sekolah dengan (menggunakan) sepeda.'

(11) 風で学校を休みます。 Kaze de gakkou o yasumimasu. Angin karena sekolah istirahat 'Karena (masuk) angin, tidak (masuk) sekolah.'

(12) 雨でテニスができませんでした。

ame de tenisu ga dekimasendeshita. Hujan karena tenis tidak dapat melakukan 'Karena hujan, tidak dapat bermain tenis.'

(13) みんなで歌を歌います。

Minna de utau utaimasu.

Semua dengan menyanyi

'menyanyi (secara bersama-sama) dengan semuanya..'

(14) 二人で旅行に行きます。 futari de ryokuou ni ikimasu.

Berdua piknik

'Piknik berdua.'

(15) 二十歳で大学に入りました。 Nijuu sai de daigakuni hairimashita. 20 tahun pada perguruan tinggi ke masuk 'Pada usia 20 tahun, memasuki Perguruan Tinggi.'

(16) カップラーメンは 3 分でできました。 Kappu ramen wa 3 fun de dekimashita.

Cup ramen 3 menit dalam matang 'Cup ramen dapat matang dalam waktu 3 menit.'

(17) 東京で地震がありました。

Tokyo de jishin ga arimashita.

Tokyo di gempa bumi ada 
'Di Tokyo ada gempa bumi.'

(18) 駅前で家事がありました。

Eki mae de kaji ga arimashita.

Statsiun depan di kebakaran ada

'Ada kebakaran di depan statsiun.'

Kehadiran joshi de pada contoh (9) dan (10), berfungsi sebagai postposisi yang dapat mengungkapkan makna instrumental. Hal tersebut diwujudkan melalui hubungan antara nomina takbernyawa yaitu hashi 'sumpit' pada contoh (9) dan jitensha 'sepeda' pada (10). Yang diikuti postposisi de. Konstruksi frasa postposisi seperti demikian menggambarkan adanya alat yang digunakan (oleh pelaku) yang diacu oleh masing-masing verbanya.

Pada contoh (11) dan (12), joshi de berfungsi sebagai postposisi pengungkap makna kausalitas yang tercermin dari sebab yang menyertainya. Postposisi jenis ini cenderung didahului oleh frasa nominal (pewatas), yaitu Kaze de 'karena masuk angin; (11) dan ame de 'karena hujan' (12). Selain itu, konstruksi frasa seperti ini dapat mengungkapkan makna eksperimental atau pengalam yang diungkapkan melalui verba pengungkap sensasional.

Joshi de yang berfungsi postposisi pada (13) dan (14) mengungkapkan makna komitatif (kesertaan) yang diwujudkan oleh postposisi de 'bersama dengan' yang sifatnya mendampingi' seperti frasa minna de 'dengan seluruhnya' pada (13) dan futari de ' berdua' pada (14) atau dapat dinyatakan bahwa frasa potposisi seperti demikian menggambarkan adanya pronomina yang melakukan aktivitas secara bersama-sama.

Berbeda dengan contoh-contoh sebelumnya, joshi de yang berfungsi sebagai postposisi pada (15) dan (16) merupakan konsep semantik pengungkap makna temporalitas yang berhubungan dengan unsur waktu.Makna temporal diungkapkan melalui postposisi de 'pada' yang diikuti pewatas numeralia (deiktik). Pada contoh (15) diungkapkan melalui frasa numeralia nijuusai de 'dalam usia 20 tahun', pada (16) melalui frasa numeralia san fun de 'dalam waktu tiga menit'.

Postposisi de 'di' pengungkap makna lokasional tampak pada contoh (17) yang diungkapkan melalui frasa postposisional Tokyo de 'di Tokyo' (pewatas) dan pada (18) melalui frasa postposisional Eki mae de 'di depan statsiun'. Klausa pada contoh tersebut menggambarkan verba aktivitas yang ditandai dengan adanya peristiwa yang sedang berlangsung.

\subsection{Joshi o}

Kehadiran sebuah kalimat dengan melibatkan partikel $o$ selain dapat berfungsi sebagai pemarkah objek dan/atau mengungkapkan dua jenis makna aspektualitas yaitu achievements atau accopmlishment (transisional) seperti pada contoh-contoh berikut.

19) 車は道の左がわを走ります。

Kuruma wa michi no hidari gawa o hasirimasu

Kendaraan jalan kiri sebelah melaju

'Kendaraan melaju di sebelah kiri jalan' 
(20)かいだんをあがります。

kaidan o agarimasu

tangga naik

'Naik (ke) tangga'

(21) 電車をおります。

Densha o orimasu

Trem turun

'Turun (dari) trem.'

(22) 大学を卒業します。

Daigaku o sotsugyou shimasu

Universitas lulus

'Lulus dari Universitas.'

Secara sintaksis, kehadiran partikel o pada contoh (15) sampai (22) berkategori postposisional yang berfungsi sebagai penguasa (government) dan didahului oleh nomina/ frasa nomina sebagai pembatas (binding). Secara semantis, keajegan linearisatas pembataspenguasa tersebut dapat mengungkapkan berbagai jenis makna.

Contoh (19) dan (20) mengungkapkan makna accomplishment (transisional) (非限界 Higenkai 'atelis'). Postposisi o yang mendahului verba pengungkap makna atelis tersebut melibatkan lajur tema (path of the theme), berhubungan dengan spasio temporal yang berekivalen dengan skema gerak (move) sebagai pewatas verba. Dalam frasa hidari gawa 'sebelah kanan' pada contoh (19) dan kaidan 'tangga' pada (20) bukan merupakan tujuan (Goal), tetapi memiliki arti melewati untuk menuju ke suatu tempat (whole path of the motion).

Postposisi o pada contoh (21) dan (22) mengungkapkan makna achievement (完了 'kanryou' perfektif') atau pungtual (瞬間 'shunkan' pungtual') yang diikuti verba pungtual orimasu 'turun' pada (17) dan sotsugyou shimasu 'lulus (dari Peguruan tinggi). Verba jenis ini memiliki persamaan dengan verba aktivitas akan tetapi tidak mengacu terhadap situasi yang sedang berlangsung/terjadi dalam satu saat dan menempati waktu tertentu. Atau dapat dinyatakan bahwa postposisi $o$ yang diikuti verba tersebut merupakan akhir dari suatu kegiatan yang tidak dapat dibatasi oleh waktu secara eksplisit.

\section{Simpulan}

Hasil penelitian menunjukkan bahwa kehadiran joshi ni, de, dan o dalam BJ memiliki perilaku yang berlainan dan bersifat semantik fungsional karena dapat mewujudkan berbagai jenis makna.

Secara sintaksis, keselarasan pola urutan kata BJ menunjukan adanya konstruksi postposisional yang sangat ajeg yaitu modifier (pewatas) selalui mendahului inti (penguasa). Konstituen postposisi berfungsi untuk menandai hubungan antara konstituen di depan postposisi dengan konstituen di belakangnya. Hubungan pembatas - penguasa tersebut 
digunakan untuk mengkaji hubungan antara nomina/pronomina dengan postposisi dan postposisi dengan verba yang diacunya. Penguasa (government) dipahami sebagai unsur yang menentukan hubungan antara inti konstruksi dan kategori lainnya yang ada hubungannya dengan konstruksi tersebut sedangkan pembatas (binding) dipahami sebagai unsur yang dikuasainya.

Kehadiran joshi ni dalam bentuk postposisi tidak hanya dapat mengungkapkan makna statis seperti pada contoh (5) dan (6) tetapi dapat pula mengungkapkan situasi dinamis seperti pada (7) dan (8). Selain itu, joshi ni dapat berfungsi sebagai pemarkah objek tak langsung seperti pada (3).

Konstruksi postposisional dengan melibatkan joshi de memiliki enam jenis makna yaitu pengungkap makna instrumental seperti pada (9) dan (10), kausalitas (11) dan (12), komitatif (13) dan (14), temporalitas (15) dan (16), serta pengungkap makna lokasional seperti pada contoh (17) dan (18).

Secara sintaktis, joshi o dapat berfungsi sebagai pemarkah objek seperti pada contoh (3). Secara semantis dapat mengungkapkan makna transisional seperti pada contoh (19) dan (20) dan makna perfektif (pungtual-perfektif). Makna perspektif seperti demikian menggambarkan adanya hubungan semantis antara nomina + postposisi $o$ dengan verba yang mengungkapkan ihwal titik awal dari suatu aktivitas (Origin or starting point of motion). 


\section{Daftar Pustaka}

Alwi,dkk. 1998. Tata Bahasa Baku Bahasa Indonesia. Jakarta: Balai Pustaka

Atachi Akiko,et.al. 2007, 文法が弱いあなたへ Printed in Japan.

Comrie, Bernard.1981. Language Universals and Linguistics Typology: Syntax and Morphology. Oxford: Basil Blackwell

Croff, William. 1989. Typology and Universals. Cambridge: Cambridge University Press.

Djajasudarma, Fatimah. 1990. "Situasi Telis-Atelis dan keaspekan PerfektifImperfektif melalui Verba Dinamis-Statif." Dalam Linguistik Indonesia, Tahun 8 No.1. Jakarta: Lembaga Bahasa Universitas Atma Jaya,

Hajime Takamizawa, et.al. 2004. 新。はじめての日本語虚行く教育 TokyoJapan: Ask Press

Ishibashi Reiko. 2006, 中上級日本語表現文型 Printed in Japan

Kikuko tatematsu. 1994. 日本語の手紙の書き方. Tokyo-Japan: The Japan Times-Inter-University Center for Japanese language Studies.

Kridalaksana, Harimukti. 2001. Kamus Linguistik. Jakarta: PT Gramedia Pustaka Utama.

Kudoo, Mayumi. 1995. Asupekuto, Tensu Taikei to Tekusuto. Gendai Nihonggo no Jikan no Hyoogen. Japan: Hitsuji Shoboo.

Rostini, Titien. 2003. "Aspektualitas Bahasa Jepang: Kajian Sintaksis dan Semantik. Bandung." Program Pascasarjana Universitas Padjadjaran.

-------2006. "Tata Bahasa Kasus Bahasa Inggris Versi Fillmore (1970) dalam Kalimat Bahasa Jepang: Kajian Sintaksis dan Semantik." Bandung: Jurusan Bahasa Jepang STAB Yapari-ABA Bandung.

2008. "Pemanfaatan Metode dan teknik Distribusional dalam Kajian Sistem Kala Bahasa Jepang." Bandung, Seminar Nasional Implementasi Proses Belajar Mengajar Keterampilan Berbahasa Jepang, Program Studi Bahasa Jepang Universitas Widyatama.

-------2007. Fungsi Partikel dalam Bahasa Jepang. Jakarta, Konferensi Linguistik Internasional ke-5, Pusat Kajian Bahasa UNIKA Atma Jaya.

-------2010. Analisis Linguistik Kontrastif Verba Statif dalam Bahasa Inggris-Bahasa Jepang. Bandung: Jurnal Sastra Jepang FASA UNIKA Maranatha.

-------2010. "Perilaku Sintaktis 'Jibun' dalam Kalimat Bahasa Jepang: Kajian Anaforis dan Kataforis." Bandung, Jurnal Pendidikan Bahasa Jepang-Korwil Jabar/ FPBS Universitas Pendidikan UPI..

2011. "Perihal Aspektualitas dan Sistem Kala Bahasa Jepang: Kajian Morfologi dan Semantik." Humaniora, Jurnal Budaya, Sastra, dan Bahasa. Yogyakarta: FIB Gajah Mada.

Seichi, Makino \& Michio Tsutsui. 1986, A Dictionary of Basic Japanese Grammar. Japan: The Japan Times Ltd. 199, A Dictionary of Intermediate Japanese Grammar. Japan: The Japan Times Ltd. 
Sobarna, Cece. 2003. Preposisi Bahasa Sunda: Satu Kajian Struktur dan Semantik. Bandung: Program Pascarajana Universitas Padjadjaran.

Tatsuya Nagashima. 1983. Nihonggo Bunpou Handobukku. Japan: Pana-Lingua Institute of Japanese Language.

Tadjuddin, M. 1993-a. Pengungkapan Makna Aspektualitas Bahasa Rusia dalam Bahasa Indonesia: Suatu telaah tentang Aspek dan Aksionalitas. Penerbit Pusat pembinaan dan pengembangan Bahasa, Jakarta.

Yamazaki Masatoshi, et.al.1994, ロングマン言語学用語 辞典 Printed in Japan 